\title{
Die akkommodering en bestuur van diversiteit in gemeenteverband
}

\author{
T F J Dreyer \\ Hervormde Teologiese Kollege \\ Universiteit van Pretoria
}

\begin{abstract}
The accommodation and management of diversity at congregational level

Diversity is becomming a prominent phenomenon of our society within a postmodern context. Many clergy and church members believe it threatens the peace and stability of churches and local congregations. Seemingly, diversity contributes to the escalation of conflict and the stress levels church leaders are experiencing. This article attempts to analize and describe the phenomenon of diversity from the angles of postmodernity, personality preferences and systems thinking. The research is based upon the hypothesis that diversity does not necessarily threaten the unity of local congregations. The manifestation of unity within diversity is only possible if leaders are sensitized to manage the challenges of pluriformity.
\end{abstract}

'n Onlangse opname in Amerika het getoon dat kerkleiers 25-40\% van hulle tyd spandeer aan die hantering van spanning in die gemeente (Armour \& Browning 1995:5).

\begin{abstract}
The primary culprit, most say, is diversity: too many people with too many different ideas about how things ought to be done. In one sense this is nothing new. The church has arbitrated divergent views ever since the day of Pentacost. Still, the problem is particularly acute as we approach the twenty-first century. Urbinization and technology have served up an unprecedented range of personal options, leading to highly individualized lifestyles. Diversity reigns supreme, from our choice of foods in the dairy case to our choice of jobs in the marketplace to our choice of entertainment on weekends. With personal tastes so varied, is it any wonder that we disagree on how to "do church"?
\end{abstract}

(Armour \& Browning 1995:6) 


\section{INLEIDING}

Die kerk word in haar wese gekenmerk deur 'n kleurryke verskeidenheid van gawes, voorkeure en persoonlikhede. In 1 Korinthiërs 3 poog Paulus alreeds om verdeeldheid en groepvorming in die gemeente, as gevolg van diversiteit, te besweer. In hoofstuk 12 gebruik hy die beeld van die menslike liggaam om die eenheid in die verskeidenheid te beklemtoon (vgl ook Rom 12:3-8; Ef 4:17). Deur die eeue heen kon en het die kerk tot 'n sekere mate diversiteit getolereer en geakkommodeer. Uit bogenoemde opmerking van Browning word dit egter duidelik dat dit vir gemeentelike leiers deesdae al hoe moeiliker word om diversiteit op gemeentelike vlak te bestuur. In ondersoeke word aangetoon dat een van die redes vir uitbranding onder predikante ook verband hou met die stres wat die hantering van diversiteit meebring (vgl Oswald 1998:vii; Hands \& Fehr 1994:7-14; Oswald \& Kroeger 1999:4-7).

Meer gefokus op die tradisionele hoofstroomkerke In Suid-Afrika, het die proses van verandering sedert 1994, ook daartoe bygedra dat diversiteit op kerklike terrein skerper afgeëts word. Die Nederduitse Gereformeerde Kerk het reeds 'n skeuring beleef met die stigting van die Afrikaanse Protestantse Kerk. Binne die Nederduitsch Hervormde Kerk dui die elektroniese verspreiding van "Leer en Lewenskwessies in Suid-Afrika" deur die HCM Fourie-Stigting op dieselfde tendens. Die besluite tydens die laaste Sinode van die Gereformeerde Kerke in Suid-Afrika oor die toelating van die vrou tot die ampte en die hewige debatte wat in die openbare pers gevolg het, is ook 'n aanduiding van hierdie diversiteit wat na die oppervlak kom. Die proses van eenwording binne die kerkfamilie van die NG Kerk word bemoeilik deur die vraag hoe diversiteit geakkommodeer moet word (vgl Bauman 1996:7-17). 'n Diepgaande ondersoek binne die NG Kerk (Janse 2002) toon oortuigend aan dat indien verskillende spiritualiteitstipes met gepaardgaande behoeftes nie erken word nie, dit tot konflik in gemeentes kan lei. Die Hervormde Kerk het tydens 'n Colloquium (NHKA 2006) ${ }^{1}$ wat op 27-29 April 2006 gehou is, 'n verklaring van voorneme uitgereik waarin onder andere gestel word: "God se betrokkenheid by mense is só ryk dat dit nie volledig in een vorm uitgedruk kan word nie. Die kerk van Christus is veelkleurig. Hierdie verskeidenheid word aangetref onder kerke, gemeentes en gelowiges."

Op gemeentelike vlak worstel predikante met die realiteit dat lidmate verskillende verwagtings koester ten opsigte van hulle belewenis van die liturgie, prediking en aktiwiteite van die gemeente.

\footnotetext{
${ }^{1}$ Die Colloquium was 'n byeenkoms van ampsdraers en lidmate vanuit al die ringe van die kerk. Die oogmerk van die byeenkoms was dat daar saam besin sal word oor die identiteit en relevansie van die kerk in die tyd waarin ons leef. 'n Gesamentlike verklaring van voorneme is na afloop van die byeenkoms uitgereik.
} 
In hierdie artikel word die verskynsel van diversiteit vanuit verskillende lense ondersoek. Die hipotese van die studie is dat 'n postmoderne verstaan van eenheid, die ruimte bied om diversiteit tot 'n groot mate te akkommodeer. Ten slotte sal gepoog word om enkele kontoere te trek wat, toegespits op die Nederduitsch Hervormde Kerk, gemeentelike leiers kan help om diversiteit te bestuur.

\section{DIVERSITEIT AS 'N GEGEWE}

Die samelewing waarin die kerk haar bevind word gekenmerk deur diversiteit, pluriformiteit en individualiteit. Ongeag vanuit watter perspektief 'n mens na die verskeidenheid kyk, word dit algemeen aanvaar dat alles-insluitende sisteme en homogene denke iets van die verlede is. "Viewed from a systems perspective, your congregation is not merely a group of people brought together by common beliefs and aspirations. It is a complex pattern of human networks playing off one another" (Armour \& Browning 1995:7). Die diversiteit beteken nie noodwendig dat mense só van mekaar verskil dat hulle nie meer oor basiese sake kan ooreenstem nie. Mense se denkpatrone vertoon terreine van oorvleueling oor gemeenskaplike sake, maar die verskil kom na vore in die toepassing en prioretisering daarvan. Veskeidenheid kom ook sterker na vore wanneer dit gaan oor sake wat op die periferie lê. Fondamentalisme ${ }^{2}$ het in die verlede twee belangrike funksies in die samelewing vervul. Eerstens, het dit die gewaarwording van sosiale kohesie versterk en tweedens, het dit 'n kriterium daargestel waaraan kompeterende opvattings van die waarheid getoets kon word (Lose 2003:13). Hierdie waarheidsopvattings is beklee met 'n semi-goddelike status en gelegitimeer en toegepas deur magstrukture. Die reaksie teen fondamentalisme is nie soseer gerig teen kohesie nie, maar wel teen die statiese karakter daarvan (Lose 2003:17). Wanneer mense dit bevraagteken, gaan dit gewoonlik gepaard met etikettering soos; moeilikheidmakers, manteldraaiers, liberaliste, en ketters. Dit lei tot spanning, verdagmakery en polarisering (Armour \& Browning 1995:17). "While the church has always contended with diversity and tension, those forces are now at unprecedented levels. Congregational leadership must reconcile a range of views and outlooks unlike any we have seen before" (Armour \& Browning 1995:17).

Hierdie diversiteit en gepaardgaande spanning kan destruktief op die kerk inwerk indien 'n mens dit bloot negatief bejeën. 'n Mens kan ook diversiteit in die kerk as 'n gegewe, miskien dalk juis 'n Godgegewe, waardeer, en die energie wat daaruit voortvloei tot voordeel van die kerk

\footnotetext{
${ }^{2}$ Fondamentalisme word hier gebruik as vertaling vir "foundationalism". Fondamentalisme kan nie as sinoniem vir fundamentalisme gebruik word nie.
} 
bestuur. Om dit moontlik te maak moet ons eers die dinamika onderliggend aan hierdie gegewe probeer verstaan. Die laaste vyf dekades is daar baie navorsing gedoen oor die funksionering van die menslike denke. In toenemende mate word tot die gevolgtrekking gekom dat mense nie die werklikheid op dieselfde wyse waarneem en interpreteer nie. Sommiges is regterbrein dominant, terwyl ander linkerbrein dominant is; party verkies visuele leer, terwyl ander weer meer gemaklik is met ouditiewe leer; Sommiges prosesseer idees deur beelde terwyl ander mense dit doen deur interne dialoog of deur die nagaan van feite (Armour \& Browning 1995:8). "The single most powerful statement to come out of brain research ... is this: We are as different from one another on the inside of our heads as we appear to be different on the outside of our heads" (Fulgum 1989:40).

Hierdie pluriformiteit wat in toenemende mate in die samelewing manifesteer, kan vanuit verskillende perspektiewe ondersoek en beskryf word, byvoorbeeld: die paradigmaskuif na postmoderniteit; sisteemteorieë en denksisteme; die effek van die wêrelddorp; die invloed van die media en die internet; persoonlikheidstipes en -voorkeure; spiritualiteitstipes. Daar is 'n verskeidenheid lense wat gebruik kan word om na die fenomeen te kyk en dit te probeer verstaan. In hierdie ondersoek word daar veral gefokus op postmoderniteit, persoonlikheidsvoorkeure en -tipes, asook die invloed van denksisteme, om diversiteit te belig.

\subsection{Die invloed van postmoderniteit}

'n Mens raak al huiwerig vir die begrip postmoderniteit omdat dit 'n gonswoord geword het wat kwistig aangewend word om allerlei nuwe tendense te verklaar en te legitimeer. Daar is al in eie geledere baie gepubliseer oor die sogenaamde postmoderne lewensgevoel, asook oor die epistemologiese aanpak daarvan (Janse van Rensburg 2000; Thompson 2000; Dreyer 1997). Pieterse (2002:78), stel dat die woord "postmodern" nie lekker op sy tong lê nie, omdat modernisme nog steeds belangrike aspekte van ons natuurwetenskaplike navorsing, tegniek, ekonomiese stelsels en denkwyses bepaal. Hy kies om saam met Schweitzer (2001:173) liewer van refleksiewe moderniteit te praat, omdat ons onsself in 'n oorgangstyd bevind. Janse van Rensburg (2003:8) is van oordeel dat ons hedendaags te doen het met drie tipes mense: die postmoderne mense, die mense wat bewustelik of onbewustelik beïnvloed is deur postmoderne idees en mense wat postmodernisme verwerp. Hoe dit ookal sy, die hedendaagse konteks adem tot 'n groot mate 'n postmoderne lewensklimaat waarvan die kerk nie gevrywaar is nie. Postmoderniteit is die bedding waarbinne pluraliteit en diversiteit floreer. 
Die bedoeling is nie om hier in diepte in te gaan op die debat oor postmoderniteit nie, maar om die invloed van postmoderne denke op die fenoneem van diversiteit te omlyn. Postmoderniteit is in 'n sekere sin 'n reaksie op die fondamentalisme wat kenmerkend van die modernisme is. Fondamentalisme is begrond in objektiewe waarhede wat tot uitdrukking kom in oorkoepelende sosiale stelsels en strukture wat die waarhede beskerm en in stand hou. Die proses van legitimering van hierdie stelsels gaan gewoonlik gepaard met die uitoefening van mag wat in die strukture setel (vgl Lose 2003:12-17; Lyotard 1993:41). Sodoende word eenheid van denke en kohesie tot 'n groot mate beskerm en in stand gehou. Dit is binne hierdie paradigma waarin die kerkordelike strukture, belydenisgeskrifte en liturgiese vorme sedert die Reformasie gestalte gevind en vir vier eeue feitlik onveranderd gehandhaaf is.

Die postmoderne filosofie staan skepties teenoor die rol wat aan die rede en aan die mens as rasionele subjek toegeken word. Die kille rasionaliteit word verbreed tot 'n ryke redelikheid waarin emosionaliteit, estetiek en retoriek 'n sentrale funksie kry (Burggraeve \& Velle 1993:11). Die fokus het verskuif vanaf 'n modernistiese proklamering van ewige waarhede na 'n post-moderne soeke na sin te midde van die kompleksiteit van diverse kontekste van elke individu (Janse van Rensburg 2000:9). Waarheid hou altyd verband met die subjektiewe perspektief van die individu en berus op 'n netwerk van interafhanklike oortuigings. "In place of a foundationally ordered, centered structure, postmodernists offer a picture of a heteronomous dissensus of competing claims and voices where no idea or voice is privileged over the rest" (Lose 2003:17). Die problematiek waarvoor die samelewing en die kerk te staan gekom het, is die vraag na die waarheid, omdat waarheid binne 'n postmoderne konteks gerelativeer word tot 'n subjektiewe verstaan van die werklikheid ... "truth, like beauty, seems increasingly to be in the eye of the beholder" (Lose 2003:2).

Postmoderniteit is nie slegs ' $n$ idee nie, dit is deel van 'n breër en dieper proses van verandering wat wêreldwyd manifesteer. Namate die wêreld krimp as gevolg van globalisering en ons deel word van die wêrelddorp, bevind ons ons toenemend in 'n konteks van pluralisme en diversiteit (Kennedy 1992:506, vgl ook Le Bruyns 2004:343-345; Hanson 2005:132-134). Sweet (1999:17) vergelyk die impak van die postmoderne denke met 'n Tsoenami-golf wat ons gaan tref. Selfs in homogene gemeenskappe, soos wat die Afrikaanse kerke in Suid-Afrika vir 'n lang tyd was, word pluralisme deel van ons werklikheid. "Some postmodern thinkers affirm that we do not have pluralism, but that we 'are' plural" (Kennedy 1992:507). 
In Suid-Afrika het ons iets van die dramatiese verandering begin belewe sedert die politieke verandering in 1994. Ons is geneig om die oorsake van die verandering slegs toe te skryf aan die nuwe staatkundige bedeling, terwyl die staatkundige verandering plaaslik maar ' $n$ simptoom is van die Tsoenami wat besig is om te breek. Die groter prentjie is dat ons blootgestel word aan 'n proses van globalisering en postmoderne denke wat via die televisie en die Internet deel van ons alledaagse lewe geword het. In ons samelewing is drastiese veranderings besig om plaas te vind wat die kerk en elkeen van ons se lewe raak. Ons was gewoond daaraan dat die openbare lewe tot 'n groot mate deur die kerk en Christelike waardes bepaal was. Daar was wetgewing wat pornografie, seksuele wanpraktyke en sedelike verval gestuit het. Wetgewing het die Sondag as Christelike feesdag beskerm. Skole het Bybelonderrig gehad, 'n Christelike, Afrikaanse etos het die karakter van skole bepaal, streng dissipline is gehandhaaf en kinders is geleer om hulle aan gesag te onderwerp.

Die openbare mening is besig om ingrypend verander. Let wel, ek sê nie dit het verander nie, maar dit is steeds besig om te verander. In die verlede is, in 'n ekologiese werklikheidverstaan, verandering as 'n abnormaliteit gesien. In 'n nuwe ekologiese verstaan word verandering as 'n normale deel van die werklikheid verstaan. Voortdurende verandering het gekom om te bly - dit is die normale nie net in die natuur nie, maar ook binne die sosiale prosesse. Dit is juis deel van die postmoderne denke wat ons oorspoel. Die tyd waarbinne vaste reëls, wette en instellings met gesag afgedwing kon word, is verby. Die meeste van die kriteria, waarvolgens mense in die verlede as fatsoenlike burgers beoordeel is, het weggeval. Vryheid van keuse, smaak en spraak word deur 'n handves van menseregte gewaarborg. Mense behoort nie meer aan 'n kerk omdat dit van hulle verwag word nie. Juis omdat hulle dikwels nie meer in die institusionele kerke met hulle reëls en dogma's 'n geestelike tuiste vind waar hulle waarlik die gemeenskap met God en medegelowiges beleef nie, soek hulle dit elders. 'n Diversiteit in spiritualiteitstipes kom na vore in die verskillende verwagtings wat mense het van die prediking, liturgiese ervarings en gemeentelike aktiwiteite.

Diversiteit en pluraliteit word dikwels deur ampsdraers en lidmate in die kerk bedreigend ervaar. "We want to keep things under control - under our control! So pluralism often seems threatening to us. ... I just want everything to go smooth!" (Kennedy 1992:308). 


\subsection{Die erkenning van persoonlike voorkeure}

Die verskil in mense se persoonlikheidstipes en -voorkeure, wat 'n invloed op menslike gedrag uitoefen, is al deur talle wetenskaplikes vanuit verskillende perspektiewe nagevors (vgl Briggs 1987:19-41; Lundin 1966:1-3; Allport 1961:567-573; Jung 1954). Die Myers-Briggs Type Indicator (MBTI) is 'n toeganklike meetinstrument, gebaseer op die navorsing van Jung, wat die invloed van persoonlike voorkeure in normale gedrag aandui. Hierdie meetinstrument word oor 'n wye front beskou as die mees-gebruikte persoonlikheidsmeting in die geskiedenis (Oswald \& Kruger 1999; Francis 1997; Goldsmith 1997).

Die doel van hierdie instrument is om mense te help om hulleself en ander se voorkeure te verstaan en te waardeer. Dit lei weer tot groter begrip om ander nie as vreemd, verkeerd of ongewoon te beskou nie. Mense verskil van mekaar op grond van hierdie voorkeure, of persoonlikheidstipes. Voorkeure en tipes is ook nie staties nie, maar 'n dinamiese groeiproses (Bayne 1995:2; Briggs Myers 1995:1). Verskille tussen mense is nie die gevolg van toeval nie, maar is die logiese gevolg van 'n paar basiese verskille in die manier hoe mense verkies om hulle denkaktiwiteite te benut. Dit hou verband met die wyse van waarneming en besluitneming (Briggs Myers 1995:1). Waarneming kan plaasvind op 'n kontinuum van sintuiglike (detail) tot intuïtiewe waarneming (groter samehang). Besluitneming op grond van dit wat waargeneem is, word weer bepaal deur 'n voorkeur van 'n denkende (klinies, feitlik, logies) tot 'n meer gevoelsmatige (begrip vir die invloed op mense en waardes) proses. Energering vind ook by mense op verskillende wyses plaas. Vanaf 'n ekstroverte lewenshouding waar energie buite jouself in die wêreld van verhoudings en aktiwiteite gevind word, tot 'n meer introverte lewenshouding waar energie geput word in die binnewêreld van denke, stilte en alleenwees. Hierdie voorkeure manifesteer in 'n manier van lewe wat of aan die een kant gekenmerk word deur 'n besliste, geordende, of aan die ander kant, 'n meer vloeibare en plooibare lewenstyl. Voorkeure kan in 'n verskeidenheid kombinasies na vore kom, wat aanleiding gee tot verskillende temperamente en 16 persoonlikheidstipes (vgl Briggs Myers 1995).

Dominante voorkeure word bepaal deur oorerwing (geneties) en omgewingsfaktore (opvoeding, omgewing, aanleer). Voorkeure en persoonlikheidstipes is egter nie in beton gegiet nie, maar is 'n dinamiese proses van verandering en groei. Situasies kan mense noop om sekondêre, of tersiêre voorkeure te gebruik en verder te ontwikkel.

Oswald \& Kruger (1999) het die resultate van hierdie meetinstrument toegepas op die gemeentelike lewe en die rol van kerklike leiers. In hulle navorsing word geïllustreer wat die invloed van persoonlike voorkeure op 


\section{Die akkommodering en bestuur van diversiteit in gemeenteverband}

spiritualiteit, Skrifverstaan, prediking, gebed, leierskapstyle, liturgiese ervarings en gemeentelike aktiwiteite is. Hierdie verskille beteken nie noodwendig dat een reg en die ander verkeerd is nie, maar dat pluriformiteit en diversiteit 'n gegewe is wat verband hou met persoonlikheidstipes.

In 'n gemeenskap wat gedomineer word deur 'n moderne paradigma waar objektiewe waarhede in 'n geslote sisteem met gesag afgedwing word, kan persoonlike voorkeure deur die konteks onderdruk word. Binne 'n postmoderne konteks kom hierdie persoonlike voorkeure baie sterker na vore. Die verskynsel van lidmate wat verskillende denominasies se eredienste bywoon op soek na liturgiese ervarings wat hulle behoeftes bevredig, is die manifestasie van persoonlike voorkeure wat in 'n postmoderne konteks na die oppervlak kom.

\subsection{Die dinamika van denksisteme}

Armour en Browning (1995) het in 'n omvattende publikasie die navorsing van Graves (1974) oor die dinamika van denksisteme, toegepas op die kerk. Die titel van hulle boek dui reeds op hulle oogmerk met die publikasie: "Systemssensitive leadership. Empowering diversity without polarizing the church." Hulle kyk deur die lens van verskillende denksisteme na die diversiteit in die kerk. Wanneer die dinamika van die denksisteme beter begryp word, en kerkleiers 'n sensitiwiteit daarvoor ontwikkel, kan diversiteit 'n positiewe krag in die kerklike en gemeentelike lewe word.

Graves het voortgebou op die navorsing van Maslow se behoeftepiramiede wat uitgaan van die standpunt dat wanneer behoeftes op een vlak bevredig word, 'n mens na 'n volgende vlak van behoeftebevrediging beweeg. Graves se navorsing toon aan dat nuwe omstandighede nie slegs behoeftes en motivering verander nie. Veranderde omstandighede sneller nuwe denksisteme, elk met sy eie unieke motiverings en behoeftes. Denksisteme beïnvloed nie net die motivering van mense nie, maar ook hulle interpersoonlike, organisatoriese en etiese prioriteite (Armour \& Browning 1995:13). Binne 'n sisteem, soos 'n gemeente, is daar altyd 'n dominante denksisteem wat oorheers, terwyl daar ander denksisteme is wat nie geakkommodeer word nie - dit is die resep vir konflik! 'n Beknopte oorsig van die agt verskillende denksistme kan daartoe bydra om die dinamika en interaksie van diverse denksisteme beter te begryp (vgl Armour \& Browning 1995:51-121).

\subsubsection{Sisteem 1}

Word gekenmerk deur die basiese eksistensiële behoefte van oorlewing te midde van onmiddellike bedreigings. Aktiwiteite van die groep is ingestel op voorsiening van voedsel en beskerming teen bedreigings. 


\subsubsection{Sisteem 2}

Word gekenmerk deur die strewe na persoonlike veiligheid in 'n wêreld van onsigbare kragte en magte. Vorm groepe, of "clans" wat 'n gemeenskaplike veilige, of heilige plek, deel. Gee op spirituele vlak uitdrukking aan 'n immanente god wat teenwoordig is en ingryp in die alledaagse. Vrees die oordeel en vloek van God, daarom speel godsdienstige rituele en heilige voorwerpe 'n groot rol. Persooonlike vryheid word onderdruk deur tradisie en groepskohesie.

\subsubsection{Sisteem 3}

Hier verskuif die aksent vanaf persoonlike veiligheid te midde van die bedreiging van onsigbare magte, na fisiese veiligheid waar mense hulle moet beskerm in die aangesig van dreigende menslike magte. Hiërargiese strukture word gevestig met 'n sterk outoritêre figuur as die hoof. Sekere voorregte en luukses is net beskore vir die boonste laag van die hiërargie. In familieverband moet mans sterk wees om gevare van buite die hoof te bied, terwyl vroue se regte en voorregte tot die huis beperk is. God word gerespekteer op grond van goddelike almag en krag. Goddelike ingrype sal die mens red van gevare.

\subsubsection{Sisteem 4}

Morele en sosiale stabiliteit word binne hierdie sisteem die belangrikste dryfveer. Strukture, reëls en regulasies word deur besluitnemers in die hoogste posisies in 'n burokratiese stelsel afgedwing. Leiers met integriteit word feitlik blindelings gevolg. Die huisgesin word die ruimte vir morele vorming binne die kader van respek vir die ouers. God is die skepper en outeur van ewige waarhede. Bybelse gesag word hooggeag, want dit is die bron vir beginsels en waardes. Dit lei tot intensiewe teologiebeoefening omdat hierdie beginsels tot in die fynste detail uitgewerk moet word. Mense word geleer deur te luister na gesagsfigure. Leergierigheid, as 'n soeke na waarheid en valsheid, is kenmerkend binne die sisteem. Sterk gemeenskappe, gebou op morele waardes, is tiperend. Die sisteem word in stand gehou deur enige vorm van verandering, as bedreiging af te weer.

\subsubsection{Sisteem 5}

Die strewe na persoonlike sukses en prestasies word in hierdie sisteem die katalisator. Die aandrang op konformiteit, onderdruk mense se innerlike behoefte om persoonlike vervulling. Kompetente organisasies, gedryf deur missies, visies en doelwitte moet lei tot resultate en effektiwiteit. Leiers is mense wat dinge laat gebeur en resultate behaal. Hulle is mentors en nie 
"base" in die tradisionele sin van die woord nie. Die uitgebreide familie maak plek vir die kerngesin. Vroue is gelykes wat ook 'n loopbaan buite die huis volg. Kinders moet presteer en hulle bekwaam vir die regte professies. Beweeglikheid en aktiwiteite van gesinslede beperk familietyd tot die minimum. God is ' $n$ Vriend op die lewenspad. Op grond van elkeen se spirituele gawes, word geleenthede gesoek om dit aan te wend in diens van God. Kerkgeboue moet van sukses en status getuig en die optrede van ampsdraers, moet professioneel wees. Redding manifesteer in die transformasie na die beeld van God. Stel meer belang in praktiese as dogmatiese teologie. Sulke mense hou van probleemoplossings en toetsing van idees onder leiding van 'n mentor wat kompetent is.

\subsubsection{Sisteem 6}

In 'n wêreld wat gekenmerk word deur onsensitiwiteit, vervreemding en uitbuiting, soek hierdie mense na intimiteit en wedersydse ondersteuning. Klein groepies met sterk onderlinge bande in egalitêre verhoudings bevredig die behoefte. Leiers maak plek vir fasiliteerders wat roteer en besluite berus op konsensus. Die gesinslewe is die ruimte waar almal op gelyke vlak gedagtes en emosies kan uitruil. Lyfstraf is feitlik uitgedien en gesamentlike familie-aktiwiteite word beplan en beskerm. God is vir hulle die Heler en die Een wat versoening tussen mense bring. Die erediens moet lei tot diep religieuse ervarings en mense tot introspeksie bring, veral om 'n bewussyn te kweek teenoor diegene wat magteloos en verwond is. Hierdie mense het 'n aversie teenoor oororganisering en strukture.

\subsubsection{Sisteem 7}

Die verskynsel van polarisering, rigiede standpunte en partisane wat mense in opponerende kampe verdeel, wek by hierdie groep die behoefte aan buigsaamheid en aanpasbaarheid. Organisasies moet vinnig kan aanpas by veranderende omstandighede. Besluitneming vind plaas in 'n netwerk van verhoudings binne 'n neutrale struktuur. In gesinsverband is daar ruimte vir verandering van roetine en rolle. Druk word nie toegepas om te konformeer aan 'n familie-stereotipering nie. God is vir hulle die Een wat alles integreer om as 'n geheel te funksioneer. Hulle put spirituele inspirasie vanuit 'n verskeidenheid bronne, veral religieuse literatuur. Geloof beteken 'n lewe in harmonie met die goddelike ekologiese prosesse. Hulle geniet selfleerervarings gebaseer op persoonlike behoeftes met behulp van tegnologie. Hulle sien die "groter prentjie" en voel nie bedreig deur verandering nie. 


\subsubsection{Sisteem 8}

'n Oortuiging dat die hele menslike ras een is, in 'n enkele wêrelddorp woon en dat almal gelyke toegang tot die reserwe bronne van die planeet moet hê, word die motivering van mense binne hierdie sisteem. Alliansies van mense met kundigheid werk saam om oplossings vir probleme te vind wat etniese en nasionale grense transendeer. Leiers met langtermyn visies en holistiese perspektiewe werk saam om makro-probleme op te los. In familieverband, word kinders opgevoed as kinders van die wêrelddorp wat bereid moet wees om persoonlike opofferings te maak ter wille van die welstand van alle kreature. God is die hoogs metafisiese Wese agter alles. Mense wil 'n persoonlike verbintenis ervaar met hierdie Bron van alle eksistensie. Geloof bring ' $n$ kosmiese bewussyn van wie ons is binne 'n groter geheel. Transkulturele en trans-etniese vriendskappe word gesluit met 'n toespitsing op die ekologie.

\subsubsection{Die impak van denksisteme op die sisteem van die kerk}

Denksisteme, soos kortliks hierbo verduidelik, vorm 'n handige lens om die fenomeen van diversiteit beter te begryp. Tot 'n groot mate verdiskonteer die verskillende denksisteme ook die paradigma-verskuiwing vanaf pre-modern, na modernisme en die reaksie van post-moderniteit. Die MBTI wat 'n mens bewus maak van die pluriformiteit van voorkeure in menslike gedrag, kan ook binne die raamwerk van denksisteme geïnterpreteer word, omdat nuwe situasies 'n mens dikwels noop om dominante voorkeure te verruil vir sekondêre, of tersiêre voorkeure. Dit is veral sisteme 6 tot 8 wat ruimte bied vir hierdie verskeidenheid van voorkeure.

Tot en met die laaste helfte van die twintigste eeu was sisteem 4 die dominante modaliteit in die meeste gemeentes. Hierdie sisteem het leierskapstyle, preekstyle, liturgiese vormgewing, argitekstyle vir kerkgeboue en onderrig-/opvoedingstyle bepaal. Sisteem 5 en 6 het egter die sisteem 4 denke begin oorwoeker en sisteem 7 is besig om vinnig veld te wen. In 'n opname van Armour en Browning (1995:149) onder kerkleiers in Amerika, word die verspreiding van denksisteme soos volg in persentasies uitgedruk:

- Sisteem $3-1 \%$

- Sisteem $4-45 \%$

- Sisteem $5-22 \%$

- Sisteem $6-22 \%$

- Sisteem $7-10 \%$ 


\section{Die akkommodering en bestuur van diversiteit in gemeenteverband}

Die verskuiwing van denksisteme is 'n voortdurende proses wat gekenmerk word deur fases van vinnige progressie en dan weer konsolidering. Ouderdom het nie noodwendig 'n invloed op jou denksisteme nie. Dit is 'n denkfout om te aanvaar dat ouer persone meer tuisvoel binne sisteme 3-5 en jonger mense in 6-7. Die verspreiding hou nie direk met ouderdoms-groeperinge verband nie. Nuwe denksisteme vervang nie voriges nie, maar bou daarop voort. Vroeëre modelle is steeds beskikbaar en somtyds vereis omstandighede dat daarop teruggeval word. Binne 'n sisteem soos 'n gemeente verkry 'n bepaalde denksisteem, of selfs meer as een, naderhand die status van die dominante denksisteem wat die ander oorwoeker (Armour \& Browning 1995:42-45). Dit is veral wanneer sisteme 4, 5 en 6 met mekaar kompeteer dat die konflikpotensiaal verhoog. Die aard van sisteem 4 is dat mense van nature versigtig en konserwatief is en nie maklik afstand doen van die beproefde nie. In kontras met 4, is 5 en 6 meer innoverend en spontaan. Sisteem 4 sal verandering ondersteun as hulle die veranderingsagente vertrou. Waar vertroue ontbreek, lei dit tot vrees en opponering. Die interessante is dat persone van sisteem 4 luidkeels protes aanteken op vergaderings, of by wyse van briewe hulle misnoë te kenne gee. Mense van sisteem 5-8, is meer tolererend en akkommoderend en sal later, indien hulle nie vordering bespeur nie, bloot stilweg verdwyn en 'n ander geestelike tuiste soek (Armour \& Browning 1995:169-179).

Binne die Nederduitsch Hervormde Kerk van Afrika het hierdie verskuiwing van denksisteme tot woelinge, onsekerheid en selfs tot groepvorming en modaliteitsvorming aanleiding gegee. Die Agendas van die Kerk (Nederduitsch Hervormde Kerk van Afrika:1998, 2001 en 2004 voortaan NHKA) weerspieël hierdie dinamika in debatte oor: belydenis (NHKA 1998:43 vv; 2001:50-55; 2004:45-46); Skrifbeskouing (NHKA 2004:62-68); wisselformuliere (NHKA 2004:45-62); liturgie (NHKA 2004:252-270); homoseksualiteit (NHKA 2004:394-424). Meningsverskille wat hierin na vore kom, is simptomaties van die verandering van dominante denksisteme.

Die dringende vraag onderliggend aan die fenomeen van diversiteit en pluriformiteit in die gemeenskap en die kerk is: hoe moet ons dit bejeën en hanteer? Indien kerke en gemeentes hierdie verskynsel en die dinamika daarvan nie reg bestuur nie, kan dit tot konflik, groepvorming, vyandigheid en selfs kerkskeuring lei. Armour en Browning (1995:133-257) bepleit 'n sisteemsensitiewe leierskap wat 'n multi-sisteemkerk so bestuur dat dit 'n nuwe dimensie aan kerkwees en 'n kragtige momentum aan die kerklike lewe kan bied. 


\section{EENHEID IN VERSKEIDENHEID}

In die verlede het eenheid en homogene denke gestalte gevind in strukture wat dit beskerm en in stand gehou het. Eenheid is in modernistiese sin bedink in terme van een struktuur waarbinne enersdenkendes hulle afgegrens het teen "afwykende" menings. Ekumeniese bewegings het hulle beywer vir strukturele eenwording wat die eenheid van die kerk sou vergestalt. Hierdie strukturele eenheidstrewe het dikwels die diversiteit misken.

Binne 'n postmoderne paradigma (sisteem 5-8), word eenheid nie gesien as die teenpool van diversiteit nie, maar word eenheid juis bedink in terme van die ruimte wat gebied word vir diversiteit. Eenheid in verskeidenheid is die motto ( $\mathrm{vgl}$ Armour \& Browning 1995:23-25; Buitendag 2005:45-63; Buitendag 2002:1-25). Die werklikheid waarbinne ons lewe vertoon immers 'n geskakeerdheid. Veelkleurigheid, pluriformiteit en diversiteit verbreed en verryk ons werklikheidsverstaan. In plaas daarvan om in te fokus op die kleiner eenhede, word uitgefokus op die groter prentjie sodat die verskillende nuanses raakgesien kan word. Dit is 'n mosaïek van kleure en patrone. Elke afsonderlike onderdeel is uniek en is nodig om die groter beeld te vorm. Dit beteken nie dat die grense en lyne vervaag nie, want dan verdwyn die groter beeld. Dit is juis die grense en lyne van die onderskeie dele wat die groter beeld vorm gee.

Dit impliseer nie dat daar geen grense is en dat alles gerelativeer word nie. "Respek vir verskille en partikulariteit bestaan dus en daarom ook eie oortuigings met die korrektief van toereikende kategotrieë" (Buitendag 2002:17). Lindbeck (1989:271) noem dit "reconciliation without capitulation". Mens-wees speel altyd af binne die wisselwerking van enkeling en groep, tradisie en ervaring en binne hierdie netwerk leef die mens en maak keuses, assosiasies en disosiasies. (Buitendag 2004:76). 'n Bepaalde geloofsgemeenskap vorm 'n nis waarbinne mense 'n geestelike tuiste vind, op grond van bepaalde oortuigings, keuses en spiritualiteitstipes. Daar is ' $n$ verskeidenheid "sacred canopies" waarbinne mense tot hulle reg kan kom. Die keuse lê by die individu om binne ' $n$ bepaalde nis te eksisteer of nie (Buitendag 2004:78). Elke kerk of geloofsgemeenskap sal 'n tuiste bied aan mense met bepaalde spiritualiteitstipes en voorkeure. 'n Geloofsgemeenskap bied ruimte vir verskeidenheid en toleransie binne sekere kontoere. Spiritualiteit en identiteit hou verband met die teologiese etos van 'n kerk (Dreyer 1998:289-314). Binne die Hervormde Kerk is daar ruimte vir verskillende aksente, maar altyd binne die kontoere van die teologiese etos. Sekere kenmerke en waardes van die spiritualiteit van die kerk vorm hierdie kontoere. Die liturgie van die Hervormde Kerk sal byvoorbeeld altyd gekenmerk word deur gewydheid, eerbied, nederigheid en orde, omdat ons 


\title{
Die akkommodering en bestuur van diversiteit in gemeenteverband
}

maar te goed besef dat ons in die teenwoordigheid van die gansandere God is (vgl Dreyer 1998; 1999:255-269). Die besluite van die Algemene Kerkvergadering oor die liturgie (NHKA 2004:252-270) skep die ruimte vir afwisseling en verskeidenheid, maar tegelyk word die parameters wat die aard en karakter van die erediens stempel, omlyn.

Die Hervormde Kerk se teologiese etos word meestal met die begrip Bybels-Reformatories aangedui. Kenmerkend van die Kerk se teologie is dat dit 'n poging is om binne 'n dialektiese idioom oor God, en mense se geloof in God, te praat. Die eie aard van die Hervormde Kerk se teologie word kernagtig saamgevat in die verklaring wat na afloop van die reeds genoemde Colloquium uitgereik is:

\begin{abstract}
Ons onderskei tussen 'n "belydeniskerk" en 'n "belydende kerk". Die Hervormde Kerk wil belydende kerk wees. Die waarheid kan nie volledig in 'n leer vasgevat word nie. Waarheid is in die eerste instansie 'n Persoon en oorstyg alle menslike pogings tot formulering. Vir ' $n$ institusionele kerk wat 'n belydende kerk wil wees, kom kerkwees primêr neer op 'n "lewenskwessie" en nie 'n "leerkwessie" nie. Ons leef in God se teenwoordigheid alleen op grond van die genade. In aansluiting by belydenisvorming in die verlede, word in elke nuwe konteks weer nuut bely. Die uitdrukking daarvan kan moontlik anders wees as in die verlede. Ons is terdeë bewus daarvan dat God groot is en ons klein. Dit maak ons beskeie wanneer ons oor God praat. ... God se betrokkenheid by mense is só ryk dat dit nie volledig in een vorm uitgedruk kan word nie. Die kerk van Christus is veelkleurig. Hierdie verskeidenheid word aangetref onder kerke, gemeentes en gelowiges. Skakeringe in spiritualiteit, ervarings van God en liturgiese vorme word daarom gerespekteer binne die kontoere van die kerklike tradisie en is verrykend. Ons sien pluriformiteit en diversiteit nie as 'n bedreiging nie en oordeel nie dat almal uit een mond hoef te praat nie. Die eenheid van die kerk, en nie die verskeidenheid nie, is egter wel die evangeliese eis. Eie voorkeure mag nie tot konflik of onenigheid lei nie, maar moet saamklink soos 'n simfonie tot eer van God.
\end{abstract}

(NHKA 2006)

Uit hierdie enkele opmerkings blyk voldoende dat, binne sekere buitelyne, daar genoegsame buigbaarheid en ruimte bestaan om diversiteit te akkommodeer, sonder dat die eenheid geskaad hoef te word. Die groot uitdaging is egter om hierdie eenheid in verskeidenheid so te bestuur dat die konflikpotensiaal ontlont kan word. 


\section{DIE FASILITERING EN BESTUUR VAN DIVERSITEIT OP GEMEENTE-VLAK}

Met die oog op die bestuur van diversiteit word die denksisteme soos deur Armour \& Browning (1995) verduidelik, hoofsaaklik as lens gebruik, omdat dit ook tot 'n groot mate ander lense inkorporeer. Die verskynsel van diversiteit manifesteer nie in alle gemeentes ewe prominent nie. 'n Bepaalde gemeente se samestelling kan van so 'n aard wees dat die meeste lidmate hoofsaaklik tot dieselfde dominante denksisteem behoort: "Because people view things alike, they do things alike" (Armour \& Browning 1995:147). In ander gemeentes is meervoudige denksisteme aanwesig en die dominante denksisteem kom onder druk. Die verskuiwing van 'n enkele denksisteem- na 'n multi-sisteem kerk kom steeds meer na die oppervlak.

Gemeentelike leiers kan die verskynsel op verskillende maniere benader:

- $\quad$ Ignoreer die verskynsel en probeer slegs gemoedere kalmeer - dit lei tot konflik wat opbou en uiteindelik gaan uitbars.

- $\quad$ Kies vir een sisteem waarbinne jy persoonlik gemaklik voel, of wat 'n drukgroep in die gemeente vereis - dit versterk polarisasie en onenigheid.

- $\quad$ Erken die verskynsel en probeer dit met sensitiwiteit bestuur. - dit vra 'n sisteem-sensitiewe leierskapstyl wat 'n nuwe dinamika tot gevolg kan hê.

Sisteem-sensitiewe leierskap vereis dat gemeentelike leiers die tekens en simptome van multi-sisteemdenke betyds moet kan raaksien en mense van verskeie sisteme, verbaal en nie-verbaal, moet laat beleef dat daar begrip en waardering vir hulle sienswyses is. So 'n benadering sal potensiële konflik nie totaal elimineer nie, maar dit wel minimaliseer. Dit is veral in die liturgie waar die verskuiwing vanaf sisteem 4 na 5,6 , en 7 , konflik meebring. Sisteem 4 denkers het 'n dogmatiese beskouing oor die kerk, liturgie en kerklike gebruike. Bybelse "beginsels", 400 jaar se belydenisskrifte en kerkordelike reëlings legitimeer hulle denke. Sisteem 4 denkers beoordeel 'n kerk aan die standaarde, gebruike en beginsels wat gehandhaaf word, sisteem 5 aan die mate waarin spirituele behoeftes bevredig word en sisteem 6 aan die diensbaarheid van die kerk teenoor mense wat ly. Sisteem 4 verkies 'n formele, streng geordende liturgiese verloop. Sisteem 5, 6 en 7 het meer 
behoefte aan ' $n$ informele erediens en deelname. Sisteem 4 is versigtig, konserwatief en op hulle hoede vir verandering, terwyl 5 en 6 weer innoverend en spontaan is (Armour \& Browning 1995:169).

Daar is by sisteem 4 ' $n$ natuurlike weerstand teen verandering omdat dit gesien word as die dunpunt van die wig wat uiteindelik gaan lei tot die oorboord gooi van alle beginsels en tradisies. 'n Duidelik, omlynde, geleidelike en geordende prosesmatige verandering skep vertroue. Sisteem 4 denkers moet nie in die gemeentelike beplanning uitgeskuif word nie, maar juis betrek word. Hulle kritiese opmerkings moet ernstig geneem word omdat dit by hulle vertroue skep en kan help om slaggate te vermy. Die Bybel moet deurlopend 'n sentrale rol vervul, maar dan juis ook om mense bewus te maak van die verskillende maniere waarop die Bybel gelees en geïnterpreteer kan word.

Dit is onmoontlik om binne die bestek van hierdie artikel 'n omvattende strategie vir die bestuur van diversiteit te aan te bied. Die werk van Armour \& Browning (1995:133-272) kan daarvoor geraadpleeg word. Samevattend word slegs enkele riglyne gebied wat nadenke kan stimuleer.

- Maak die gemeente bewus van die verskynsel van diversiteit met klem op die feit dat die akkommodering van verskeidenheid nie noodwendig beteken dat alle beginsels vervaag nie. ' $n$ Opname om die verskillende behoeftes van gemeentelede te reflekteer, kan 'n goeie begin wees. Die resultate van hierdie opname moet deurlopend aan die gemeente gekommunikeer word. Die prediking, pastoraat, kategese, Bybelstudie, wyksbyeenkomste en vergaderings bied geleenthede vir hierdie bewusmaking.

- Skep op alle vlakke 'n atmosfeer van sensitiwiteit en toleransie vir mense se verskillende denkwyses. Kies die regte woorde waarmee mense kan identifiseer sonder om ander minderwaardig te laat voel. Verseker mense daarvan dat verskeidenheid nie beteken dat daar geen grense meer is nie, maar omlyn die kontoere van die kerklike etos waarbinne verskeidenheid geakkommodeer word.

- Stel 'n taakspan saam om 'n gemeentelike bedieningsplan te bedink wat mense se verskillende denkwyses probeer inkorporeer. So 'n taakspan moet verteenwoordigend wees van persone met verskillende denksisteme. Gereelde terugvoer (op verskillende maniere) aan die gemeente is een van die sleutelfaktore om die proses te laat slaag. 
- Oorweeg die implementering van verskillende Bybelstudiegroepe, diensgroepe en werkgroepe om mense se onderskeie behoeftes te ondervang.

- Predikers moet hulle daarop toelê om nie slegs een preekstyl te volg nie, maar juis om deur verskillende aanbiedingstyle ' $n$ verskeidenheid van verwagtings by gemeentelede te probeer akkommodeer.

- As liturg moet daar in die beplanning van die liturgie rekening gehou word met die verskillende verwagtings. Die nodige afwisseling kan aan almal die ervaring bied dat daar ook vir hulle ruimte is. Dit kan ook oorweeg word om twee eredienste te hou waar die een 'n meer tradisionele, formele liturgie handhaaf en die ander ' $n$ meer informele, deelnemende styl.

\section{Literatuurverwysings}

Allport, G W 1961. Pattern and growth in personality. New York: Holt, Rinehart \& Winston.

Armour, M C \& Browning D, 1995. Systems-sensitive leadership: Empowering diversity without polarizing the church. Missouri, MO: College Press.

Bauman, C 1996. Unity and diversity in South Africa with special regard to the unification process of the Dutch Reformed church family. MTh mini-skripsie, Universiteit van Wes-Kaapland.

Bayne, R 1995. The Myers-Briggs Type Indicator: A critical review and practical guide. London: Chapman \& Hall.

Briggs S R 1987. Personality theories: What questions are we trying to answer?, in Burke, T J (ed), Man and mind: a Christian theory of personality, 132-187. Hillside, NJ: Hillside College Press.

Briggs, M I 1995. Gifts differing: Understanding personality type. California, CA: Davies-Black.

Buitendag, J 2002. Postliberale teologie as teologiese raamwerk vir die kerk se korporatiewe identiteit. HTS 58,1-25.

Buitendag, J 2004. "Genes R us" - of juis nie. HTS 60, 61-81.

Buitendag, J 2005. Liturgie as fontein van die lewe: 'n Oorsigartikel oor die kosmiese kartering van Gordon W Lathrop se boek, Holy ground: A liturgical cosmology. HTS 61, 45-63.

Burggraeve, R \& Velle S 1993. Christendom en postmoderniteit: Doemdenken, heil, of bescheiden kansen? Collationes 1, 1-19.

Dreyer, T F J 1997. Die verhouding prediking en belydenis in 'n postmoderne konteks: 'n "Huwelik" of "saamwoon". HTS 53, 1250-1265.

Dreyer, T F J 1998. Spiritualiteit, identiteit en die etos van die Nederduitsch Hervormde Kerk. HTS 54, 289-314. 
Dreyer, T F J 1999 Hervormde etos en die roep om spiritualiteit, in Van Wyk, D J C (red), Twintigste Eeu Hervormde Teologie, 255-269. Pretoria: Sentik.

Francis, L J 1997. Personality type and Scripture: Exploring Mark's Gospel. London: Mowbray.

Fulgum, R 1989. It was on fire when I lay down on it. New York: Ivy Books.

Goldsmith, M 1997. Knowing me, knowing God: Exploring your spirituality with Myers-Briggs. Nashville, TN: Abingdon.

Graves, C W 1974. Human nature prepares for a momentous leap. The Futurist 1974, 72-78.

Hands D R \& Fehr, W L 1994. Spiritual wholeness for clergy: A new psychology of intimacy with God, self and others. New York: The Alban Institute.

Hanson, M S 2005. Growing together, Growing apart. Dialog: A Journal of Theology 44, 132-136.

Janse, R 2002. Spiritualiteitsdiversiteit as uitdaging aan die erediens: 'n Verkenning van die funksie van lofprysing in die Nederduitse Gereformeerde Kerk. DThproefskrif, Universiteit van Stellenbosch.

Jung, C J 1954. The development of personality, tr by R C F Hull, in Collected works of $C \mathrm{~J}$ Jung, Volume 17. New York: Princeton University Press.

Janse van Rensburg, J 2000. The paradigm shift: An introduction to postmodern thought and its implications for theology. Pretoria: Van Schaik.

Janse Van Rensburg, J 2001. The influence of post-modern epistemology on preaching. Acta Theologia 42, 340-347.

Janse van Rensburg, J 2003. Narrative preaching: Theory and praxis of a new way of preaching. Acta Theologica, Suppl 4.

Kennedy, W E 1992. Diversity in a postmodern context. Religious education 87, 506513.

Le Bruyns, C 2004. Reconciled diversity: Where Evangelicals and Catholics fear to tread. Religion \& Theology 11, 343-353.

Lindbeck, G A 1984. The nature of doctrine: Religion and theology in a postliberal age. Philadelphia, PA: Westminister.

Lose, D J 2003. Confessing Jesus Christ: Preaching in a postmodern world. Grand Rapids, MI: Eerdmans.

Lundin, R W 1966. Personality. Dubuque, IA: Brown.

Lyotard, J F 1993. The postmodern explained. Minneapolis, MN: University of Minnesota Press.

Nederduitsch Hervormde Kerk van Afrika 1998. Notule van die $65^{\mathrm{e}}$ Algemene Kerkvergadering. Pretoria: Kerkargief.

Nederduitsch Hervormde Kerk van Afrika 2001. Notule van die $66^{\mathrm{e}}$ Algemene Kerkvergadering. Pretoria: Kerkargief.

Nederduitsch Hervormde Kerk van Afrika 2004. Notule van die $67^{\mathrm{e}}$ Algemene Kerkvergadering. Pretoria: Kerkargief.

Nederduitsch Hervormde Kerk van Afrika 2006. Colloquium: Verklaring van voorneme. Pretoria: Kerkargief.

Oswald, R M 1998. Clergy self-care: Finding a balance for effective ministry. New York: The Alban Institute.

Oswald, R M \& Kroeger 1999. Personality type and religious leadership. New York: The Alban Institute. 
Pieterse, H J C 2002. Prediking in 'n postmoderne lewensgevoel. Praktiese Teologie in Suid-Afrika 17, 75-101.

Schweitzer, F 2001. Practical Theology and postmodern life: Do we need a new paradigm? International Journal of Practical Theology 5, 169-183.

Sweet, L 1999. Soultsunami: Sink or swim in new millennium culture. Grand Rapids, MI: Zondervan.

Thompson, C G 2000. Proclaiming the Gospel to Postmodernists. PhD Dissertation, Potchefstroom University for Christian Education. 